\title{
ANALISIS KESULITAN BELAJAR MATEMATIKA SISWA KELAS VIII SMP KATOLIK SANTO MIKAIL BALIKPAPAN DALAM MENYELESAIKAN SOAL PADA MATERI KUBUS DAN BALOK TAHUN AJARAN 2016/2017
}

\author{
Retty Anastasia Kambey ${ }^{1),(*)}$ \\ Ariantje Dimpudus ${ }^{2}$ \\ Azainil $^{3)}$ \\ 1), 2), 3) Program Studi Pendidikan Matematika, Universitas Mulawarman \\ Email: ${ }^{(*)}$ rettykambey@gmail.com
}

\begin{abstract}
ABSTRAK
Penelitian ini bertujuan untuk mengetahui jenis kesulitan belajar matematika yang dialami siswa dan mengetahui penyebab kesulitan belajar matematika yang dialami siswa. Penelitian ini bersifat deskriptif kualitatif dan dilaksanakan di SMP Katolik Santo Mikail Balikpapan tahun ajaran 2016/2017 pada pembelajaran matematika materi kubus dan balok. Subjek dalam penelitian ini adalah siswa kelas VIII B yang berjumlah 26 siswa. Kegiatan penelitian ini meliputi identifikasi kasus, identifikasi masalah, identifikasi faktor penyebab kesulitan belajar, dan prognosis. Hasil penelitian menunjukkan jenis kesulitan belajar matematika siswa dalam menyelesaikan soal kubus dan balok adalah: (1) Kesulitan menghitung dengan persentase sebanyak 17,857\%, (2) Kesulitan siswa dalam mentransfer pengetahuan dengan persentase sebanyak $24,205 \%$, (3) pemahaman bahasa matematika yang kurang dengan persentase sebanyak $33,333 \%$,

(4) kesulitan siswa dalam persepsi visual dengan persentase sebanyak $24,205 \%$. Faktor penyebab kesulitan belajar siswa dibedakan menjadi 2 yaitu faktor internal dan eksternal. Faktor internal meliputi keadaan fisik siswa, intelegensi siswa, minat siswa dan motivasi siswa. Faktor eksternal meliputi cara mengajar guru, kondisi dan keadaan kelas, kegiatan yang diikuti siswa, keadaan lingkungan rumah dan hubungan keluarga.
\end{abstract}

Kata kunci: Kesulitan, Belajar, Matematika.

\begin{abstract}
This research aims for knowing the type of learning difficulties on mathematics experienced by students, and knowing the causes of learning difficulties on mathematics experienced by students. This research is qualitative descriptive and implemented in SMP Katolik Santo Mikail Balikpapan academic year 2016/2017 on learning mathematics material cube and beam. Subjects in this study were students of class VIII B with total of 26 students. The research activities include identification of the case, identification of the problem, identification of factors causing learning difficulties, and prognosis. The results showed the type of mathematics learning difficulties for students' in solving the problem of cubes and beams are: (1) Calculating difficulties with
\end{abstract}


percentage of $17,857 \%$, (2) Student difficulties in transferring knowledge with percentage of $24,205 \%$, (3) Understanding of mathematical language that are less with percentage of $33,333 \%$, (4) Student difficulties in visual perception with percentage of $24,205 \%$. Factors that cause learning difficulties for students are divided into two, namely internal and external factors. Internal factors include physical state of students, the intelligence of students, the interest of students and motivation of students. External factors include teachers' way of teaching, the conditions and circumstances of the class, the activity that students attend, the state of home and environment and the family relationship.

Keywords: Difficulties, Learning, Mathematics.

\section{PENDAHULUAN}

Dalam proses pendidikan di sekolah, terjalin interaksi antara guru dan siswa dalam proses pembelajaran. Interaksi antara guru dan siswa inilah yang menjadi inti dari proses pendidikan secara keseluruhan untuk mencapai tujuan pembelajaran. Namun dalam pelaksanaannya, sering kali ditemui siswa yang mengalami kendala untuk mencapai tujuan pembelajaran yang akan dicapai tersebut. Salah satu penyebab siswa tidak dapat belajar sebagaimana mestinya adalah kurangnya pemahaman pada pelajaran yang telah disampaikan oleh guru mata pelajaran. Keadaan dimana siswa tidak dapat belajar sebagaimana mestinya dikarenakan beberapa faktor baik dari dalam maupun dari luar inilah yang disebut dengan kesulitan belajar. Siswa yang mengalami kesulitan belajar biasanya akan mendapatkan hasil belajar yang belum memenuhi Kriteria Ketuntasan Minimal (KKM).

Bidang studi matematika adalah salah satu bidang studi yang sifatnya bertumpu, dalam arti setiap konsep baru menuntut prasyarat pemahaman atas konsep sebelumnya. Oleh karena itu apabila terjadi ketidakpahaman pada salah satu pokok bahasannya, ketidakpahaman ini akan terbawa ke pokok bahasan berikutnya sehingga pada akhirnya guru sangat mungkin akan menjumpai banyak kegagalan dalam mengajarkan atau menjelaskan suatu konsep, dan siswa akan mengalami kesulitan dalam belajarnya. Seperti halnya bahasa, membaca, dan menulis, kesulitan belajar matematika harus diatasi sedini mungkin. Siswa akan menghadapi banyak masalah apabila kesulitan belajar matematika tidak diatasi, karena hampir semua bidang studi memerlukan matematika.

Dalam proses observasi di SMP Katolik Santo Mikail Balikpapan, peneliti menemukan adanya gejala kesulitan belajar siswa kelas VIII pada mata pelajaran matematika. Hal tersebut dapat dilihat dari rendahnya pencapaian nilai matematika pada rata-rata hasil belajar Ujian Tengah Semester Ganjil dan Ujian Akhir Semester Ganjil Tahun ajaran 2016/2017 yaitu berturut-turut adalah 56,09 dan 54,96. Perolehan nilai rata-rata tersebut masih dianggap kurang dari standar KKM yang ditentukan sekolah untuk mata pelajaran matematika yaitu nilai 70. Untuk itu kemampuan dalam menganalisis kesulitan belajar sangat

90 Analisis Kesulitan Belajar Matematika Siswa Kelas VIII SMP Katolik Santo Mikail Balikpapan Dalam Menyelesaikan Soal Pada Materi Kubus Dan Balok Tahun Ajaran 2016/2017

Retty Anastasia Kambey - Ariantje Dimpudus - Azainil 
penting dimiliki oleh seorang guru matematika. Keadaan ini harus dipandang sebagai suatu permasalahan yang harus dipecahkan atau dicari jalan keluarnya.

\section{METODE PENELITIAN}

Jenis penelitian yang digunakan adalah penelitian kualitatif dengan sifat penelitian yaitu bersifat deskriptif. Pada penelitian ini akan diperoleh informasi mengenai kesulitan belajar matematika yang dialami siswa kelas VIII SMP Katolik Santo Mikail Balikpapan dalam mengerjakan soal kubus dan balok tahun ajaran 2016/2017, sehingga dapat mengambil keputusan tentang jenis kesulitan dan faktor penyebab kesulitan belajar matematika siswa.

\section{Langkah-langkah}

dalam

menganalisis kesulitan belajar matematika adalah identifikasi kasus (mengidentifikasi siswa yang diduga mengalami kesulitan belajar), identifikasi masalah (menandai dan mengalokasikan dimana letaknya kesulitan), identifikasi faktor penyebab kesulitan belajar (menandai jenis dan karakteristik kesulitan dan faktor penyebabnya), dan prognosis (mengambil kesimpulan dan keputusan serta meramalkan kemungkinan penyebab).

Penelitian ini akan dilaksanakan Semester II pada tanggal 17 Mei 2017 sampai dengan 17 Juni 2017 tahun ajaran 2016/2017. Dengan tempat penelitian adalah SMP Katolik Santo Mikail Balikpapan. Subjek dalam penelitian ini adalah siswa kelas VIII B tahun ajaran 2016/2017 yang berjumlah 26 siswa.

Metode penentuan subjek penelitian selanjutnya akan berkembang setelah dilakukan tes oleh peneliti di sekolah.
Sedangkan objek dalam penelitian ini adalah jenis dan faktor kesulitan belajar siswa dalam menyelesaikan soal pada materi kubus dan balok.

Dalam penelitian ini, teknik pengumpulan data yang digunakan adalah teknik observasi, teknik pengukuran berupa tes formatif oleh guru dan tes tertulis oleh peneliti dimana soal yang akan diberikan sudah diujicobakan terlebih dahulu, dan yang ketiga adalah teknik komunikasi berupa wawancara kepada siswa, guru dan orang tua siswa. Adapun teknik analisis data yang digunakan yaitu reduksi data, penyajian data, serta penarikan kesimpulan.

Dari hasil tes, observasi peneliti, wawancara dan analisis langkah-langkah pengerjaan soal maka akan diperoleh informasi mengenai siswa yang mengalami kesulitan dalam menyelesaikan soal materi kubus dan balok serta jenis kesulitan yang dihadapinya.

\section{HASIL PENELITIAN DAN PEMBA- HASAN}

Identifikasi dilakukan dengan melakukan observasi kegiatan belajar siswa selama di dalam kelas terlebih dahulu. Hasil observasi yang telah dijelaskan sebelumnya menunjukkan ciriciri siswa mengalami kesulitan belajar matematika, yaitu ditandai dengan: beberapa siswa terlambat masuk kelas untuk belajar, mengantuk dan tertidur di dalam kelas, tidak aktif menjawab pertanyaan yang disampaikan guru, asik berbicara dengan teman, melamun, tidak membawa buku dan tidak mencatat serta tidak aktif bertanya kepada guru. 
Selanjutnya peneliti melanjutkan dengan melihat hasil tes formatif yang diberikan guru dan memperoleh nilai ratarata 67,923 yang masih kurang dari nilai KKM, sehingga memerlukan tes selanjutnya untuk mengidentifikasi siswa yang berkesulitan belajar.

Untuk mengidentifikasi siswa yang berkesulitan belajar, selanjutnya peneliti memberikan tes tertulis kepada seluruh siswa yang dibuat berdasarkan kesulitan yang dialami siswa pada tes formatif yang sudah diberikan oleh guru bidang studi. Adapun rata-rata dari hasil tes tertulis tersebut adalah 71,74 dan sudah memenuhi standard KKM sekolah. Dari hasil tes tertulis, terdapat 9 siswa yang memperoleh nilai kurang dari KKM sekolah yaitu siswa dengan inisial JWP, ARR, MSC, JM, MD, SG, SDS, TJT dan JN. Kesembilan siswa inilah yang teridentifikasi mengalami kesulitan belajar matematika dalam menyelesaikan soal kubus dan balok.

Tabel 1. Jumlah dan Persentase Setiap Jenis Kesulitan

\begin{tabular}{|l|l|l|l|l|l|}
\hline \multirow{2}{*}{$\begin{array}{l}\text { Nomor } \\
\text { Butir } \\
\text { Soal }\end{array}$} & \multicolumn{4}{|l}{ Jenis Kesulitan } \\
\cline { 2 - 6 } & KM & KMP & PBM & KPV & Total \\
\hline 1 & 0 & 0 & 13 & 24 & 37 \\
\hline 2 & 13 & 13 & 9 & 0 & 35 \\
\hline 3 & 8 & 6 & 6 & 0 & 20 \\
\hline 4 & 0 & 0 & 13 & 10 & 23 \\
\hline 5 & 5 & 6 & 6 & 0 & 17 \\
\hline 6 & 3 & 10 & 5 & 7 & 25 \\
\hline 7 & 1 & 6 & 4 & 0 & 11 \\
\hline Jumlah & 30 & 41 & 56 & 41 & 168 \\
\hline $\begin{array}{l}\text { Persen- } \\
\text { tase }\end{array}$ & 17,8 & 24,2 & 33,3 & 24,4 & 100 \\
\hline
\end{tabular}

Jenis kesulitan siswa yang ditemukan dari tes untuk identifikasi masalah ada 4 jenis yaitu kesulitan siswa dalam menghitung (KM), kesulitan dalam mentransfer pengetahuan (KMP), pemahaman bahasa matematika yang kurang (PBM) dan kesulitan dalam persepsi visual (KPV), yang dapat dilihat pada Tabel 1. Berdasarkan Tabel 1, diketahui bahwa kesulitan dalam pemahaman bahasa matematika yang kurang adalah yang paling banyak dialami oleh siswa yaitu dengan persentase $33,3 \%$.

Berdasarkan hasil penelitian, yang termasuk dalam kesulitan siswa pada kelemahan berhitung adalah kesulitan siswa dalam menggunakan simbol-simbol matematika serta mengoperasikan bilangan untuk menghitung luas bidang diagonal kubus yang diketahui panjang diagonal ruangnya; kesulitan menghitung luas permukaan kubus yang diketahui panjang diagonal bidangnya; kesulitan menghitung tinggi balok yang diketahui jumlah panjang rusuk, lebar dan panjang balok; serta kesulitan dalam menghitung luas permukaan balok yang diketahui volume, tinggi dan lebar balok.

Selanjutnya, yang termasuk jenis kesulitan dalam mentransfer pengetahuan yaitu kesulitan siswa dalam menghubungkan atau menggunakan apa yang diketahui pada soal untuk menjawab dan menyelesaikan pertanyaan pada soal, yaitu siswa berkesulitan menggunakan panjang diagonal ruang kubus untuk mencari luas bidang diagonal kubus; kesulitan menggunakan panjang diagonal bidang kubus untuk menghitung luas permukaan kubus; esulitan menggunakan 
jumlah panjang rusuk, lebar dan panjang balok untuk menghitung tinggi balok; kesulitan menggunakan panjang, lebar dan tinggi balok untuk menghitung bidang diagonal balok; dan kesulitan menggunakan volume, tinggi dan lebar balok untuk menghitung luas permukaan balok.

Kesulitan siswa pada pemahaman bahasa matematika yang kurang, yaitu kesulitan siswa dalam memahami bahasa matematika pada soal kubus dan balok yang diberikan, seperti kesulitan untuk memahami maksud soal untuk menuliskan diagonal-diagonal bidang pada kubus, bidang-bidang diagonal pada kubus dan diagonal-diagonal ruang pada balok.

Kesulitan siswa dalam persepsi visual yaitu kesulitan siswa memvisualisasikan unsur-unsur yang terdapat pada kubus dan balok untuk menjawab soal yang diberikan, seperti kesulitan siswa untuk memvisualisasikan rusuk-rusuk kubus, diagonal-diagonal kubus dan diagonaldiagonal ruang balok pada gambar untuk menjawab soal pada tes diagnosis.

Hasil penentuan faktor penyebab kesulitan belajar matematika siswa diperoleh peneliti melalui observasi dan wawancara siswa, guru dan orang tua siswa. Adapun hasil analisis faktor-faktor penyebab kesulitan belajar matematika siswa adalah:

\section{a. Faktor internal}

Adapun penyebab kesulitan belajar siswa yang diidentifikasi peneliti dalam penelitian ini adalah sebagai berikut:

1) Keadaan fisik siswa, meliputi (a) siswa kelelahan saat mengikuti pembelajaran matematika materi kubus dan balok dikelas, dikarenakan siswa mengikuti pelajaran PJOK sebelum pelajaran matematika, dan (b) Siswa mengantuk di dalam kelas dikarenakan pelajaran matematika pada siang hari setelah jam istirahat makan siang juga setelah pelajaran PJOK.

2) Intelegensi siswa, meliputi (a) Siswa tidak mampu menjawab beberapa pertanyaan yang diberikan guru pada saat pembelajaran berlangsung, dan (b) Siswa tidak mampu menyelesaikan jawaban dengan benar pada tes diagnostik, karena tidak menguasai materi yang diberikan guru.

3) Minat siswa, meliputi (a) Siswa terlambat masuk kelas untuk mengikuti pembelajaran matematika di kelas, (b) Siswa kurang memperhatikan saat guru menjelaskan materi kubus dan balok di kelas, dan (c) Siswa tidak membawa buku catatan dan tidak mencatat materi yang ditulis guru di papan tulis.

4) Motivasi siswa, meliputi (a) Siswa tidak memperhatikan penjelasan guru dan tertidur di dalam kelas, (b) Siswa tidak aktif bertanya dan meminta penjelasan ulang apabila ada materi yang kurang dimengerti siswa, dan (c) Siswa tidak belajar atau mengulang kembali materi yang diajarkan guru di rumah apabila tidak ada ulangan atau tugas. 
b. Faktor eksternal

Adapun penyebab kesulitan belajar siswa yang diidentifikasi peneliti dalam penelitian ini adalah sebagai berikut:

1) Cara mengajar guru, meliputi (a) Siswa mengeluh bahwa terkadang guru menjelaskan terlalu cepat, sehingga terkadang siswa menjadi bingung pada penyampaian materi oleh guru, dan (b) Pengelolaan kelas oleh guru untuk membangkitkan semangat belajar para siswa dan untuk mengkondisikan kelas.

2) Kondisi dan keadaan kelas. Siswa dan guru mengeluh keadaan kelas yang terasa panas saat siang hari dikarenakan lokasi kelas VIII yang langsung mengenai paparan sinar matahari.

3) Kegiatan yang diikuti siswa. Siswa mengikuti kegiatan ekstrakulikuler lebih dari sekali dalam seminggu dan dilaksanakan pada hari-hari yang padat dalam kegiatan belajar di sekolah.

4) Keadaan lingkungan rumah. Siswa mengeluh keadaan lingkungan rumah siswa yang ramai dikarenakan dekat pada daerah pasar, jauh dari sekolah, atau dikarenakan lingkungan rumah yang penuh dengan barang-barang karena membuka usaha toko di rumah.

5) Hubungan dengan keluarga, meliputi (a) Siswa jarang bertemu dengan orangtua, dikarenakan kesibukkan masing-masing, (b) Orang tua kurang memantau kegiatan siswa di luar sekolah, (c) Siswa memiliki hubungan yang kurang baik dengan adik atau kakak, dikarenakan sering mengganggu kenyamanan pribadi satu sama lain di dalam rumah.

Selanjutnya adalah hasil prognosis. Berdasarkan hasil identifikasi siswa yang mengalami kesulitan belajar dapat disimpulkan bahwa terdapat 9 siswa teridentifikasi mengalami kesulitan belajar matematika dalam menyelesaikan soal kubus dan balok, yang ditandai dengan perolehan nilai tes tertulis dari kesembilan siswa tersebut masih di bawah KKM sekolah yaitu 70.

Berdasarkan hasil penentuan letak kesulitan belajar, disimpulkan bahwa jenis kesulitan siswa yang ditemukan dari tes ini ada 4 jenis yaitu kesulitan siswa dalam menghitung, kesulitan dalam mentransfer pengetahuan, pemahaman bahasa matematika yang kurang dan kesulitan dalam persepsi visual. Adapun dari keempat jenis kesulitan belajar siswa tersebut, diketahui bahwa kesulitan dalam pemahaman bahasa matematika yang kurang adalah yang paling banyak dialami oleh siswa yaitu dengan persentase $33,3 \%$.

Berdasarkan hasil analisis faktor penyebab kesulitan belajar, dapat disimpulkan bahwa penyebab kesulitan belajar matematika dipengaruhi oleh faktor internal dan faktor eksternal. Faktor internal meliputi keadaan fisik siswa, intelegensi siswa, minat dan motivasi siswa. Sedangkan faktor eksternal meliputi cara mengajar guru, kondisi dan keadaan kelas, kegiatan yang diikuti siswa, keadaan lingkungan rumah dan hubungan dengan keluarga. 


\section{KESIMPULAN}

1. Jenis-jenis kesulitan siswa dalam menyelesaikan soal kubus dan balok adalah kelemahan dalam menghitung, kesulitan dalam mentransfer pengetahuan, pemahaman bahasa matematika yang kurang dan kesulitan dalam persepsi visual.

2. Faktor-faktor penyebab kesulitan siswa dalam menyelesaikan soal-soal kubus dan balok ada dua yaitu faktor internal dan faktor eksternal. Faktor internal penyebab kesulitan belajar siswa adalah keadaan fisik siswa, intelegensi siswa, minat siswa dan motivasi siswa. Adapun faktor eksternal penyebab kesulitan belajar siswa adalah cara mengajar guru, kondisi dan keadaan kelas, kegiatan yang diikuti siswa, keadaan lingkungan rumah dan hubungan dengan keluarga.

\section{DAFTAR PUSTAKA}

Abdurrahman. 2012. Anak Berkesulitan Belajar Teori, Diagnosis dan Remediasinya. Jakarta: Rineka Cipta

Ali, Moh., dan Asrori. 2014. Metodologi dan Aplikasi Riset Pendidikan. Jakarta: Bumi Aksara

Dahar, R. 2011. Teori-teori Belajar dan Pembelajaran. Jakarta: Erlangga.

Jamaris, M. 2015. Kesulitan Belajar Perspektif, Asesmen, dan Penanggulangannya. Bogor: Ghalia Indonesia

Makmun, S. 2004. Psikologi Kependidikan. Bandung: PT. Remaja Rosdakarya.
Margono, S. 2009. Metodologi Penelitian Pendidikan. Jakarta: Rineka Cipta.

Mulyadi, H. 2010. Diagnosis Kesulitan Belajar dan Bimbingan terhadap Kesulitan Belajar Khusus. Yogyakarta: Nuha Litera.

Purwanto, M. 2006. Psikologi Pendidikan. Bandung: PT. Remaja Rosdakarya.

Sugihartono, dkk. 2007. Psikologi Pendidikan. Yogyakarta: UNY Press.

Syah, M. 2010. Psikologi Belajar. Jakarta: PT. Raja Grafindo Persada. 
| Jurnal PRIMATIKA, Volume 7, Nomor 2, Desember 2018

96 Analisis Kesulitan Belajar Matematika Siswa Kelas VIII SMP Katolik Santo Mikail Balikpapan Dalam Menyelesaikan Soal Pada Materi Kubus Dan Balok Tahun Ajaran 2016/2017

Retty Anastasia Kambey - Ariantje Dimpudus - Azainil 